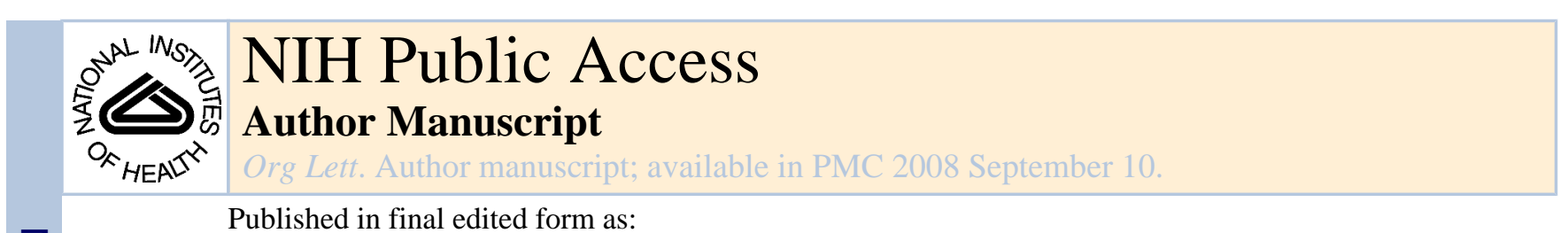

Published in final edited form as:

Org Lett. 2006 January 19; 8(2): 251-254. doi:10.1021/o1052589i.

\title{
Metal Coordination-Directed Hydroxylation of Steroids with a Novel Artificial P-450 Catalyst
}

\author{
Zhenglai Fang and Ronald Breslow ${ }^{*}$ \\ Department of Chemistry, Columbia University, New York NY 10027
}

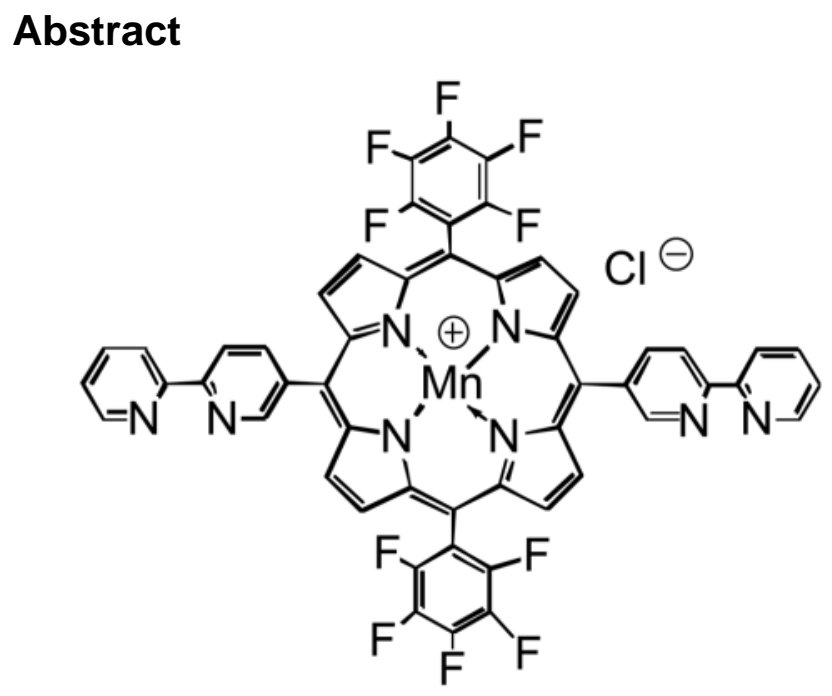

A novel catalyst has been synthesized in which a manganese-porphyrin unit is linked to two 2,2'bipyridyl groups and two pentafluorophenyl groups in trans fashion on its four meso positions. Relative to a previous catalyst in which the manganese-porphyrin had four 2,2'-bipyridyl groups, the new catalyst, in the presence of $\mathrm{Cu}^{2+}$ ions as coordinating linkers, catalyzes the oxidation of a steroid substrate with much better regioselectivity and higher turnover numbers.

\begin{abstract}
We have described hydroxylation of steroids by mimics of the enzyme cytochrome P-450 class. In our earliest examples we used metalloporphyrins carrying cyclodextrin groups to bind hydrophobic substrates in water. When the cyclodextrins were linked to p-phenylene groups attached to the porphyrin meso positions in catalyst $\mathbf{1}$, we saw highly selective hydroxylation at the C-6 alpha position of a steroid derivative $\mathbf{2}$ doubly-bound into the cyclodextrins (Figure 1). ${ }^{1}$ However, there were only about ten turnovers before the catalyst was itself oxidatively destroyed. When instead the phenylene linkers in the catalyst were replaced by tetrafluorophenylene groups in catalyst $\mathbf{3}$, we still saw hydroxylation selectively at C-6 alpha, but now with 187 turnovers before destruction of the catalyst (Figure 1). ${ }^{2}$ That same perfluorinated catalyst was also able to hydroxylate the steroid in the C-9 alpha position when a substrate was hydrophobically bound to three cyclodextrins of the catalyst. ${ }^{3}$

There could be advantages in changing the mode of substrates/catalyst binding. Hydrophobic binding is somewhat ill- defined geometrically, and it is seen only in water solvent. We had used double metal-ion coordination to bind a substrate to a metalloporphyrin and a metallosalen, and had observed good selective epoxidation of the substrate. ${ }^{4}$ Thus we used
\end{abstract}


manganese porphyrin 4 to bind and oxidize substrates, e.g. 5, in the presence of coordinating metals such as $\mathrm{Cu}^{2+}$ ions (Figure 2). ${ }^{5}$ However, the oxidation was not selective, with observed formation of six almost evenly distributed products, including 6 . Moreover, the turnover number was only 5 , low compared to the 187 turnovers we observed with catalyst 3 .

The poor catalytic performance in this biomimetic study might result from two factors- the intrinsic reactivity and the oxidative stability of catalyst $\mathbf{4}$ are significantly lower compared with catalyst $\mathbf{3}$, and the nitrogen atoms from both the manganese porphyrin and the substrate are easily oxidized to $\mathrm{N}$-oxides under the hydroxylation conditions. ${ }^{6}$ Once N-oxides are formed, the nitrogens lose the ability to coordinate to the metal center. Indeed, we isolated an initial undesired substrate oxidation product, the bis N-oxide of $\mathbf{5}$ from the hydroxylation experiments before basic hydrolysis; ${ }^{7}$ this was not further hydroxylated under the same conditions.

To avoid the undesired substrate oxidation, we attached different metal ligands to the steroid, two $\alpha$-phosphonoacetyl groups in substrate 7 (Figure 3). 8,9 When 7 was subjected to hydroxylation with iodosobenzene and the manganese porphyrin 4 in a mixture of $\mathrm{H}_{2} \mathrm{O}$ and t$\mathrm{BuOH}(1: 1)$, products resulting from hydroxylation on $5 \alpha, 6 \alpha, 7 \alpha, 7 \beta 12 \alpha$, and $14 \alpha$ positions were identified by ${ }^{1} \mathrm{H}-\mathrm{NMR} .{ }^{10,11}$ Ten catalytic turnovers were observed.

To further address the poor regioselectivity as well as the low turnover in the metal coordination-directed oxidation, we designed a new catalyst 8 with the introduction of two $\mathrm{C}_{6} \mathrm{~F}_{5}$ groups on its meso positions.

Compared to the previous manganese porphyrin catalyst $\mathbf{4}$, the new artificial P-450 catalyst $\mathbf{8}$ brought the following advantages: 1) The incorporation of two strongly electron-withdrawing pentafluorophenyl groups $\left(\mathrm{C}_{6} \mathrm{~F}_{5}\right)$ increased the enzyme's reactivity and oxidative stability, and 2) the "trans" geometrical relationship between the two bipyridyl ligands eliminates the possibility of undesired cis-binding between the artificial P-450 enzyme and the substrate, which may be the cause of some of the side reactions with catalyst 4 .

The synthesis of catalyst $\mathbf{8}$ was first attempted using either a statistical approach under standard Alder-Longo conditions 12 or an approach developed by Lindsey toward the synthesis of trans$\mathrm{A}_{2} \mathrm{~B}_{2}$-porphyrins prepared by reaction of an aldehyde and a dipyrromethane. ${ }^{13}$ However, these two attempts failed. Finally $\mathbf{8}$ was successfully synthesized following a Negishi-coupling approach (Scheme 1). The dipyrromethane ${ }^{14}$ and the commercially available pentafluorobenzaldehyde were condensed under acid conditions followed by DDQ oxidation to form a porphyrin which was immediately protected as the zinc complex 9.15 Then 9 was regioselectively brominated with $\mathrm{NBS}^{16}$ to give compound 10,17 which was coupled with a bipyridyl zinc bromide ${ }^{18}$ under Negishi conditions to give zinc porphyrin 11. ${ }^{19}$ This was demetallated with trifluoroacetic acid to give porphyrin $\mathbf{1 2}, 20$ which was then metallated with $\mathrm{MnCl} 2$ in air to give catalyst $\mathbf{8}^{21}$

As hoped, 8 catalyzed the hydroxylation of substrate 7 very regioselectively $(90 \%$ of the product) at the $6 \alpha$ position with a significantly improved turnover number of 32 (Figure 4). The significant increase in the turnover number is not surprising, considering the nonoxidizable nature of the substrate's coordination groups. The formation of an N-oxide of $\mathbf{8}$, along with other oxidative degradations, are probably the major factors that limit the turnover number to 32 in the hydroxylation of 7.

Both the selectivity and turnover number of metal coordination directed steroid hydroxylation are not yet quite as good as the hydrophobic interaction directed steroid hydroxylation by $\mathbf{3}$. However, both the regioselectivity and catalytic turnover in the hydroxylation of steroids are probably good enough for synthetic applications. This system may also be more practical since 
it will not require a water solvent and substrate water solubility for effective catalyst/substrate binding.

\section{Supplementary Material}

Refer to Web version on PubMed Central for supplementary material.

\section{Acknowledgements}

This work has been supported by the NSF and NIH.

\section{References and Notes}

1. Breslow R, Zhang X, Huang Y. J Am Chem Soc 1997;119:4535.

2. a) Breslow R, Gabriele B, Yang J. Tetrahedron Lett 1998;39:2887. (b) Yang J, Breslow R. Angew Chem B. Belvedere S, Huang Y, Breslow R. J Org Chem 2002;67:5057. [PubMed: 12126389]

3. Breslow R, Yan J, Belvedere S. Tetrahedron Lett 2002;43:363.

4. Breslow R, Brown AB, McCullough RD, White PW. J Am Chem Soc 1989;111:4517.Int Ed 2000;39:2692. (c) Breslow R, Fang Z. Tetrahedron Lett 2002;43:5197.(d) Yang, J.; Gabriele,

5. Belvedere S, Breslow R. Bioorg Chem 2001;29:321. [PubMed: 16256701]

6. Posakony JJ, Pratt RC, Rettig SJ, James BR, Skov KA. Can J Chem 1999;77:182.

7. ${ }^{1} \mathrm{H}$ NMR $\left(300 \mathrm{MHz}, \mathrm{CDCl}_{3}\right): \delta=8.80(\mathrm{~d}, 2 \mathrm{H}, \mathrm{J}=6.0 \mathrm{~Hz}), 8.37(\mathrm{~d}, 2 \mathrm{H}, \mathrm{J}=6.2 \mathrm{~Hz}), 7.90(\mathrm{~d}, 2 \mathrm{H}, \mathrm{J}=7.8$ $\mathrm{Hz}), 7.40(\mathrm{t}, 2 \mathrm{H}, \mathrm{J}=6.5 \mathrm{~Hz}), 4.97(\mathrm{~m}, 1 \mathrm{H}, \mathrm{C} 3 \alpha-\mathrm{H}), 4.86(\mathrm{t}, 1 \mathrm{H}, \mathrm{J}=7.7 \mathrm{~Hz}, \mathrm{C} 17 \alpha-\mathrm{H}), 0.91$ (s, 1H, C19$\mathrm{Me}), 0.84(\mathrm{~s}, 1 \mathrm{H}, \mathrm{C} 18-\mathrm{Me})$; Cl-MS: $535.3[\mathrm{M}+\mathrm{H}]^{+}$.

8. Da Costa CP, Song B, Gregan F, Sigel H. J Chem Soc, Dalton Trans 2000:899.

9. Compound 7 was synthesized from the commercially available $3 \beta, 17 \beta$-androstanediol and 2dibenzylphosphonate acetic acid in a 3-step procedure. ${ }^{1} \mathrm{H}$ NMR $\left(400 \mathrm{MHz}, \mathrm{D}_{2} \mathrm{O}\right): \delta=4.47(\mathrm{~m}, 1 \mathrm{H}$, $\mathrm{C} 3 \alpha-\mathrm{H}), 4.40$ (t, J=8.0 Hz, 1H, C17 $\alpha-\mathrm{H}), 2.55-2.41$ (dd, 4H), 0.670 (s, 3H, C19-Me), 0.639 (s, 3H, $\mathrm{C} 18-\mathrm{Me})$.

10. The chemical shifts of $\mathrm{C} 19$ and $\mathrm{C} 18$ angular methyl protons in the identified steroid products $\left(\mathrm{CDCl}_{3}, 400 \mathrm{MHz}\right): 3 \beta, 17 \beta$-Androstanediol (starting material): $\delta=0.819(\mathrm{C} 19-\mathrm{Me}), 0.732(\mathrm{C} 18-$ $\mathrm{Me}) ; 3 \beta, 5 \alpha, 17 \beta$-Androstanetriol: $\delta=1.003$ (C19-Me), 0.738 (C18-Me); Calculated: 1.00, 0.73;3 $\beta$, $6 \alpha, 17 \beta$-Androstanetriol: $\delta=0.833(\mathrm{C} 19-\mathrm{Me}), 0.738(\mathrm{C} 18-\mathrm{Me})$; identical to authentic sample; $3 \beta$, $7 \alpha, 17 \beta$-Androstanetriol: $\delta=0.823$ (C19-Me), 0.741 (C18-Me); Calculated: 0.81, 0.74; $3 \beta, 7 \beta, 17$ $\beta$-Androstanetriol: $\delta=0.850$ (C19-Me), 0.763 (C18-Me); Calculated: 0.85, 0.76; $3 \beta, 14 \alpha, 17 \beta$ Androstanetriol: $\delta=0.844$ (C19-Me), 0.864 (C18-Me); Calculated: 0.82, 0.85 .

11. Bhacca, NS.; Williams, DH. Applications of NMR Spectroscopy in Organic Chemistry: Illustrations from the Steroid Field. Holden-Day; San Francisco: 1964. p. 21

12. Alder AD, Longo FR, Finarelli JD, Goldmacher J, Assour J, Korsakoff L. J Org Chem 1967;32:476.

13. Rao PD, Dhanalekshmi S, Littler BJ, Lindsey JS. J Org Chem 2000;65:7323. [PubMed: 11076589]

14. Wang QM, Bruce DW. Synlett 1995:1267.

15. ${ }^{1} \mathrm{H}$ NMR (400 MHz, $\mathrm{d}_{6}$-Acetone): $\delta=10.51$ (s, 2H, meso proton), 9.61 (d, 2H, J=4.5 Hz), 9.27 (d, $2 \mathrm{H}, \mathrm{J}=4.5 \mathrm{~Hz}$ ); Cl-MS: $705.7[\mathrm{M}]^{+}$.

16. DiMagno SG, Lin V, Therien MJ. J Org Chem 1993;58:5983.

17. ${ }^{1} \mathrm{H}$ NMR (400 MHz, $\mathrm{d}_{6}$-Acetone): $\delta=9.77$ (d, 4H, J=4.7 Hz), 9.16 (d, 4H, J=4.7 Hz); Cl-MS: 863.0 $[\mathrm{M}]^{+}$.

18. Simkovsky NM, Erman M, Roberts SM, Parry DM, Baxter AD. J Chem Soc, Perkin Trans 1 2002:1847.

19. ${ }^{1} \mathrm{H}$ NMR $\left(300 \mathrm{MHz}, \mathrm{CDCl}_{3}\right): \delta=9.48(\mathrm{~s}, 2 \mathrm{H}), 9.06(\mathrm{~d}, 4 \mathrm{H}, \mathrm{J}=4.7 \mathrm{~Hz}), 8.96(\mathrm{~d}, 4 \mathrm{H}, \mathrm{J}=4.7 \mathrm{~Hz}), 8.87$ $(\mathrm{m}, 4 \mathrm{H}), 8.70(\mathrm{~m}, 4 \mathrm{H}), 8.00(\mathrm{~m}, 2 \mathrm{H}), 7.51(\mathrm{~m}, 2 \mathrm{H})$; FAB-MS: $1013[\mathrm{M}]^{+}$.

20. ${ }^{1} \mathrm{H} \mathrm{NMR}\left(300 \mathrm{MHz}, \mathrm{CDCl}_{3}\right): \delta=9.50(\mathrm{~s}, 2 \mathrm{H}), 8.99$ (d, 4H, J=4.8 Hz), $8.86(\mathrm{~m}, 8 \mathrm{H}), 8.68(\mathrm{~m}, 4 \mathrm{H})$, $7.96(\mathrm{~m}, 2 \mathrm{H}), 7.45(\mathrm{~m}, 2 \mathrm{H}),-2.80(\mathrm{~s}, 2 \mathrm{H}$, pyrrole $\mathrm{NH})$; MS (FAB): $951[\mathrm{M}]^{+} ; \mathrm{UV}$-vis $\left(\mathrm{CH}_{2} \mathrm{Cl}_{2}, \mathrm{~nm}\right)$ : 376(soret), 437, 470, 504, 544.

Org Lett. Author manuscript; available in PMC 2008 September 10. 
21. UV-vis $\left(\mathrm{CH}_{2} \mathrm{Cl}_{2}, \mathrm{~nm}\right): 331,435$ (Soret), 535, 573. 

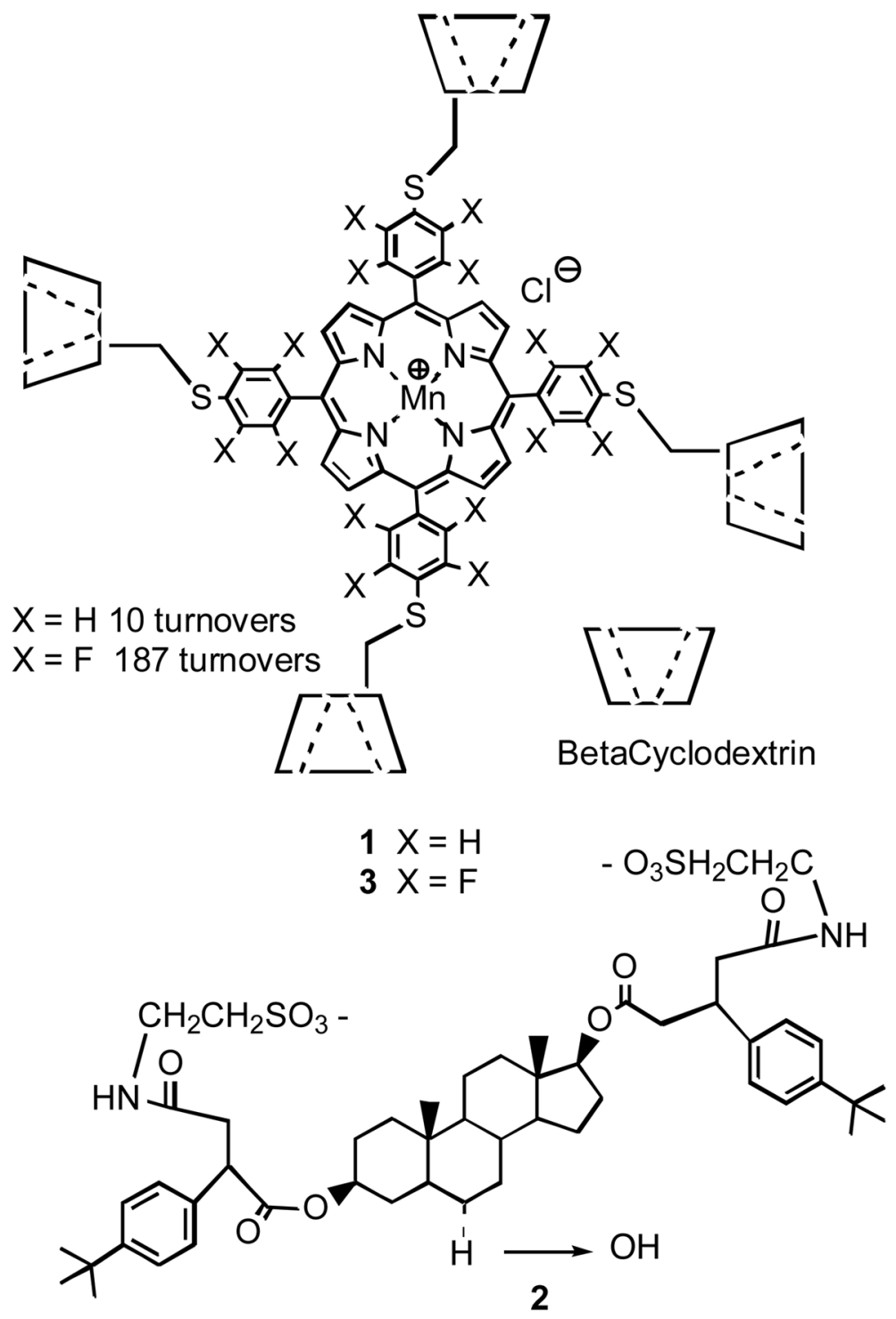

Figure 1.

Selective hydroxylation by a catalyst with attached cyclodextrins 


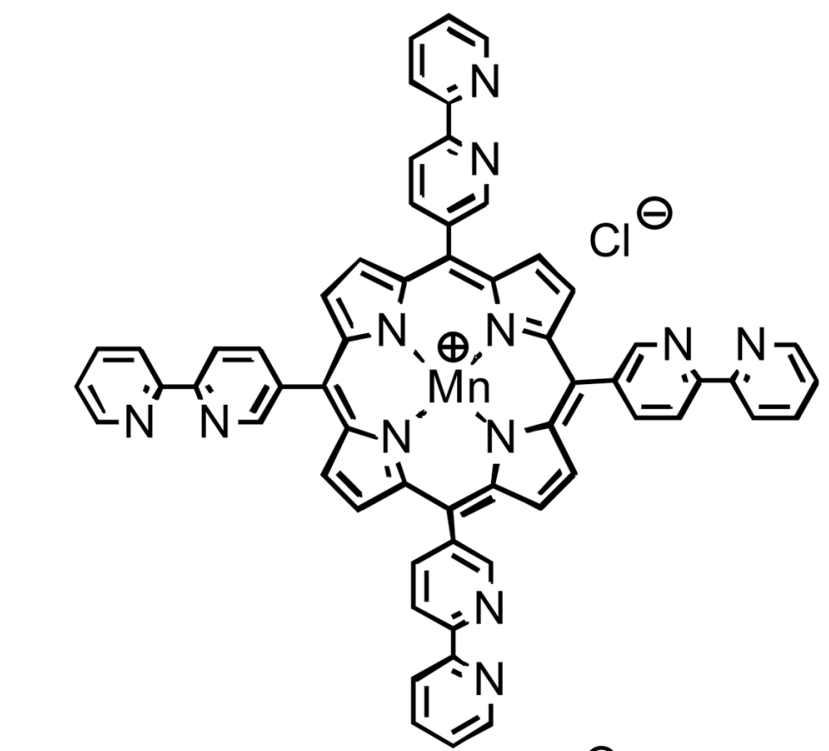<smiles>C[C@]12CC[C@H](OC(=O)c3cccnc3)CC1CCC1C2CC[C@@]2(C)C1CC[C@@H]2OC(=O)c1cccnc1</smiles>

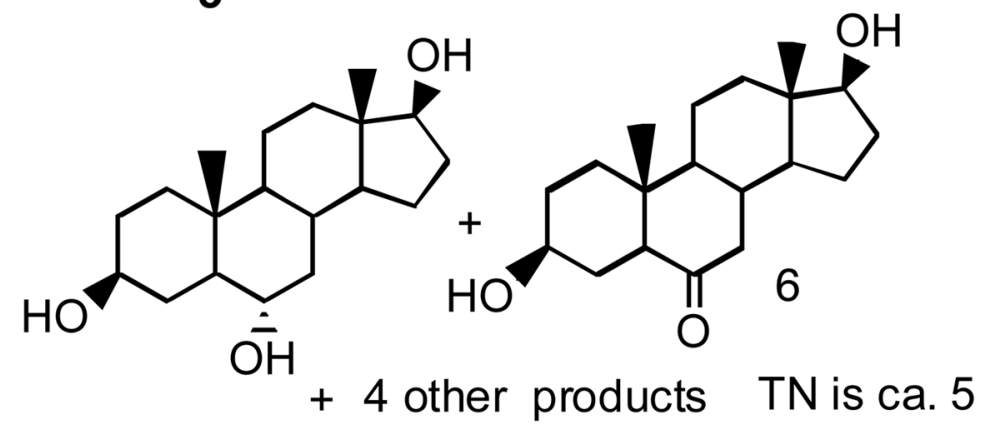

Figure 2.

Metal-coordination directed oxidation 
<smiles>C[C@]12CC[C@@H](OC(=O)CP(=O)(O[N+])O[Na])CC1CCC1C2CC[C@@]2(C)C1CC[C@@H]2OC(=O)CP(=O)(O[Na])O[Na]</smiles>

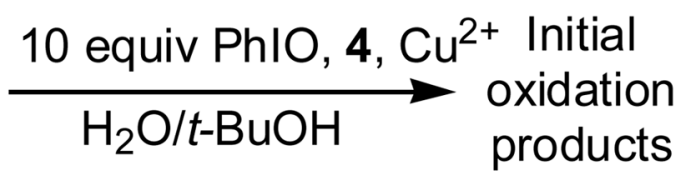

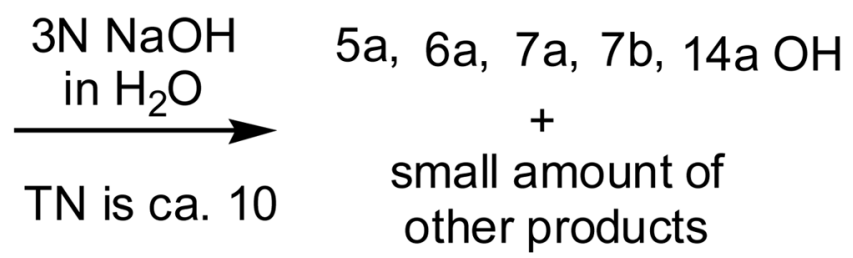

Figure 3.

Hydroxylation of substrate 7 with catalyst 4 

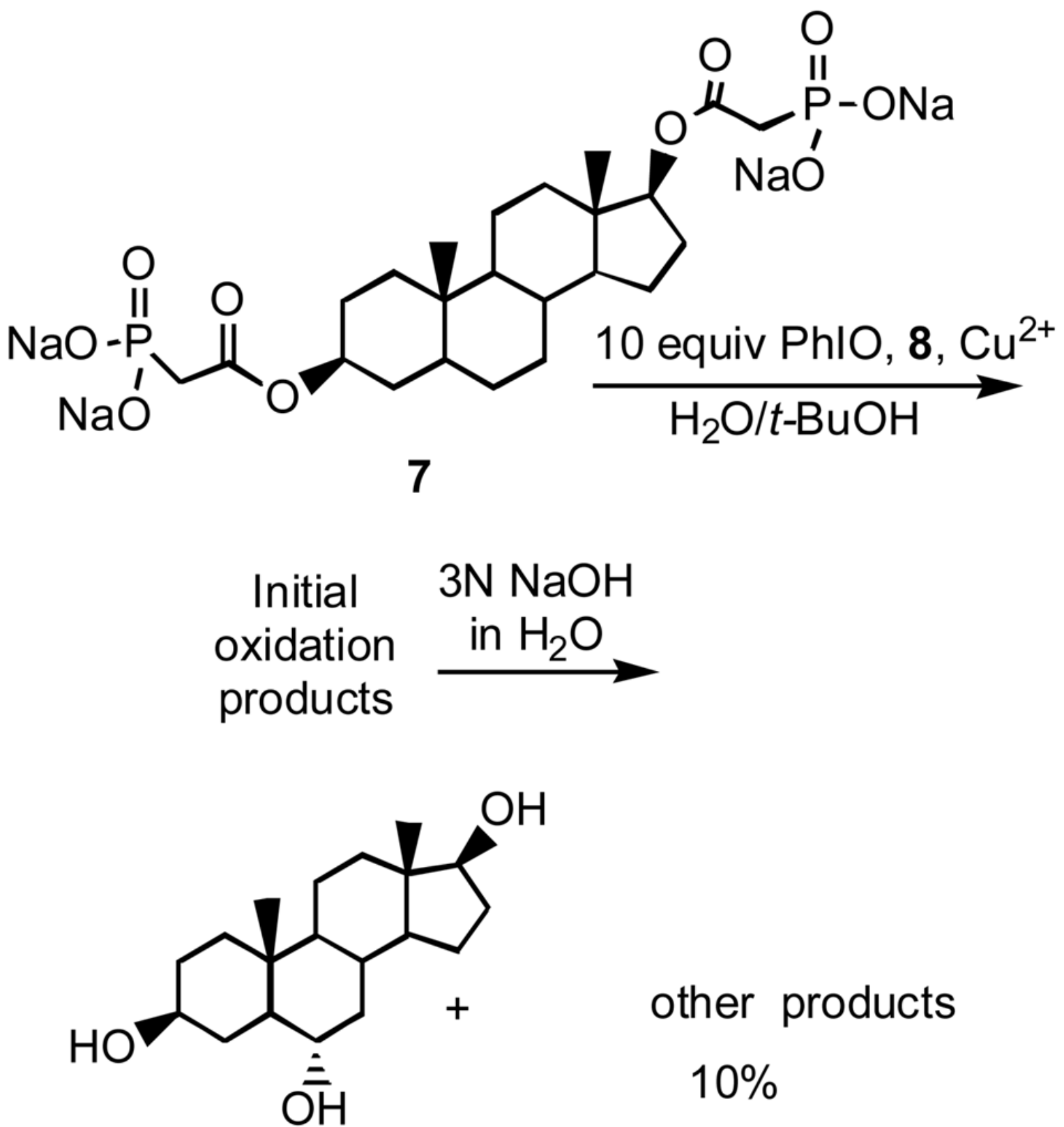

other products

$10 \%$

$390 \%$

TN is ca. 32

Figure 4.

Hydroxylation of substrate 7 with catalyst 8 

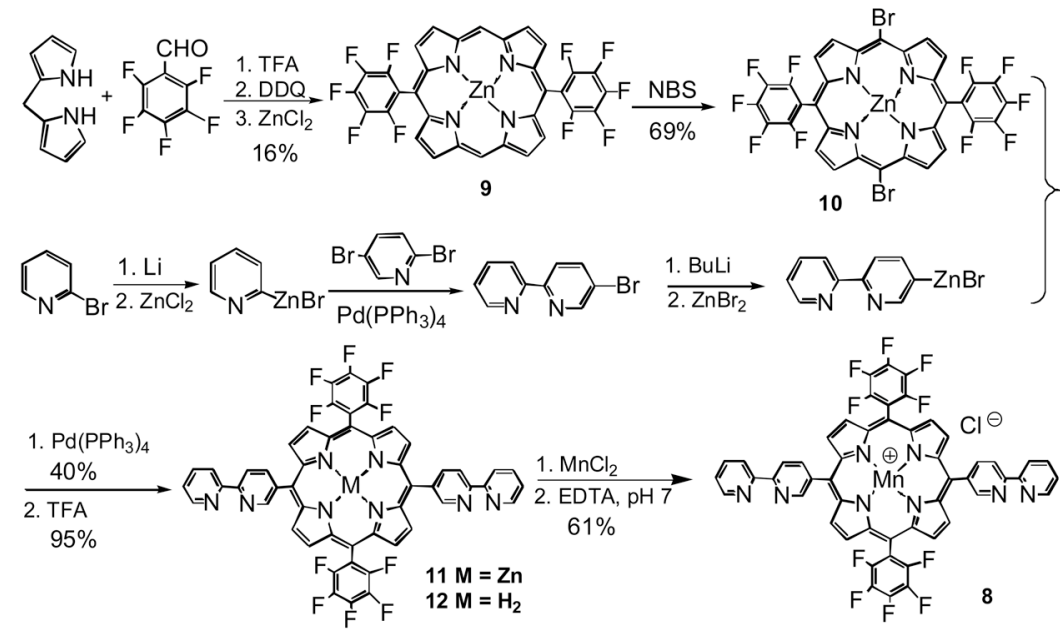

Scheme 1.

Org Lett. Author manuscript; available in PMC 2008 September 10. 